\title{
TECHNICAL AND ECONOMIC EVALUATION OF THE SEPARATION OF LIGHT OLEFINS (ETHYLENE AND PROPYLENE) BY USING $\pi$-COMPLEXATION WITH SILVER SALTS
}

\author{
Hernando-José Salgado-Gordon ${ }^{1 *}$ and Gleidy Valbuena-Moreno ${ }^{1 *}$ \\ 'Ecopetrol S.A. - Gerencia Técnica, Refinería de Barrancabermeja, Barrancabermeja, Santander, Colombia \\ e-mail: hernando.salgado@ecopetrol.com.co gleidy.valbuena@ecopetrol.com.co
}

(Received Jul. 21, 2010; Accepted May 18, 2011 )

\section{ABSTRACT}

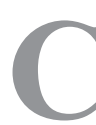

onventional processes for separation of ethylene and propylene until reaching petrochemical grade are energy intensive. Therefore, alternative separation methods, such as chemical affinity based technologies, are an interesting alternative for designing more sustainable processes. $\pi$-Complexation of the silver ion $\left(\mathrm{Ag}^{+}\right)$is one of these technologies. In this study, $\pi$-complexation is compared to the conventional technologies from process and economic points of view, in order to determine whether they are feasible to be implemented at industrial scale in both grass-roots and existing units.

Based on the results, the most promissory techniques to be applied are the Bulk Fluid Liquid Membrane -Membranas Liquidas Fluidas (BFLM- According to terms in English)- in hollow fiber modules to separate ethylene/ ethane, and absorption with an $\mathrm{AgNO}_{3}$ solution to separate propylene/propane. In addition, the implementation of hybrid processes, by combining conventional and chemical affinity technologies, provides a higher saving in the production cost when applied to revamp existing units to reduce required energy or increase processing capacity.

Keywords: Chemical affinity, Silver nitrate, Hybrid processes, Sustainable technologies.

Citation: Salgado, H. J. \& Valbuena G. (2011). Technical and economic evaluation of the separation of light olefins (ethylene and propylene) by using $\pi$-complexation with silver salts. CT\&F - Ciencia, Tecnología y Futuro, 4 (3), 73 - 88.

${ }^{*}$ To whom correspondence may be addressed 


\section{RESUMEN}

L

os procesos convencionales usados en la separación de etileno y propileno hasta grado petroquímico tienen un alto consumo de energía; por lo cual los procesos alternativos de separación, tales

como las tecnologías basadas en afinidad química, son una alternativa interesante en el diseño de procesos más sostenibles. La formación de complejos- $\pi$ entre olefinas livianas y el ión plata $\left(\mathrm{Ag}^{+}\right)$es una de esas tecnologías. En este estudio, dicha tecnología es comparada con las tecnologías convencionales mediante una evaluación desde el punto de vista de proceso y económica, con el fin de determinar si son factibles de ser implementadas a escala industrial.

Con base en los resultados, las técnicas más promisorias para ser aplicadas son la utilización de membranas líquidas -Membranas Liquidas Fluidas (BFLM- según términos de inglés)- en módulos de fibras huecas para separar etileno/etano, y la absorción en solución de $\mathrm{AgNO}_{3}$ para separar propileno/propano. Adicionalmente, la implementación de procesos híbridos combinando las tecnologías convencionales y de afinidad química, provee un mayor ahorro en los costos de producción cuando se aplican en la modificación de unidades existentes, bien sea para disminuir la energía requerida o aumentar la capacidad de procesamiento.

Palabras claves: Afinidad química, Nitrato de plata, Procesos híbridos, Tecnologías sostenibles.

\section{RESUMO}

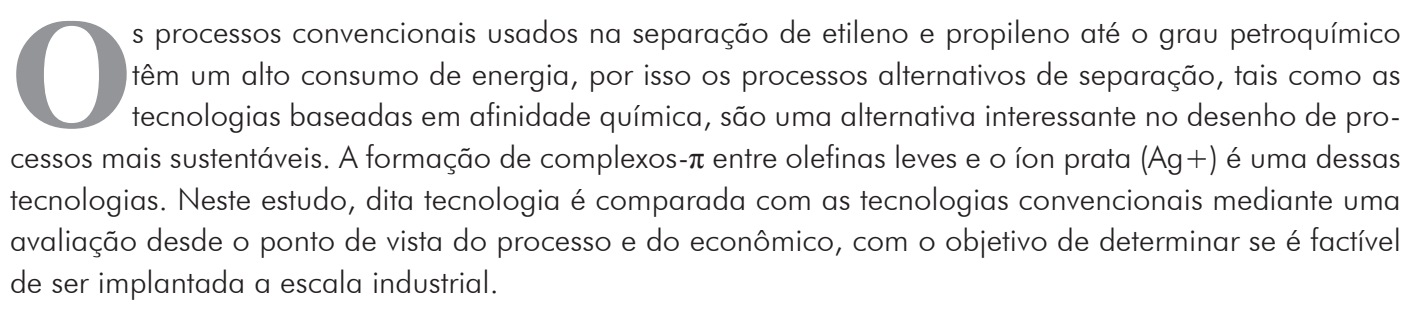

Com base nos resultados, as técnicas mais promissoras para serem aplicadas são a utilização de membranas líquidas - Membranas Líquidas Fluidas (BFLM - de acordo com a terminologia do inglês) - em módulos de fibras ocas para separar etileno/etano, e a absorção em solução de AgNO3 para separar propileno/ propano. Adicionalmente, a implantação de processos híbridos combinando as tecnologias convencionais e de afinidade química, fornece uma maior economia nos custos de produção quando são aplicados na modificação de unidades existentes, seja para diminuir a energia necessária ou para aumentar a capacidade de processamento.

Palavras chaves: Afinidade química, Nitrato de prata, Processos híbridos, Tecnologias sustentáveis. 


\section{INTRODUCTION}

The use of silver salts as a separation facilitator has been studied since 1944. In this early work, an aqueous solution of the silver salt $\mathrm{AgNO}_{3}$ at $50 \mathrm{wt} \%$ was used in the absorption and extraction of light olefins from the correspondent paraffin with similar number of carbons. According to the pilot plant data, a $95 \%$ of olefin removal and $96 \%$ of olefin purity in the extract were achieved (Pure Oil Co., 1944).

In a later study the affinity of olefins to silver salts solutions was explained in terms of the chemical complexation of olefins, or any other compound with a double bond, with the silver ion $\left(\mathrm{Ag}^{+}\right)$(Mingos, 2001). In addition, the formed complex is chemically reversible, and therefore easy to break with a relatively small amount of energy.

Considering the above, the advantage of using silver salts over the conventional separation technologies, such as distillation, is the lower energy requirements, since the separation is carried out without using any energy intensive process. Afterward, the break of the complex and purification of the component of interest can be done by using simple engineering operations, such as moderate heating or de-pressuring (Ortiz, Ruiza, Gorria \& Ortiz, 2008).

Nowadays, silver salts are already used at industrial scale in the oleo-chemical and food industry. Their main application is the extraction of PUFA's, in their methyl ester form (they are called PUFAME's or polyunsaturated fatty acid methyl esters), from fish oil raw material (cod liver oil) (Newfoundland, 1998; Li, Pittman \& Li, 2009; Li, Pham, Wang, Pittman \& Li, 2009). So far, no industrial applications in the refining or petrochemical industry have been reported.

Therefore, the aim of this study is to evaluate the feasibility of applying chemical affinity technologies at large scale in the refining and petrochemical industry. To do so, the separation of ethylene and propylene (two of the major basic petrochemicals) has been selected to compare the separation techniques based on the concept of $\pi$-complexation with $\mathrm{Ag}^{+}$and the conventional technologies (benchmark).

For each application, the benchmark was defined as the ones commonly used in the industry: cryogenic distillation for ethylene separation, and conventional distillation for propylene separation. The final evaluation was done by process and economic analysis, based on the calculated main equipment size, consumption utilities and silver salt make-up.

\section{THEORICAL FRAMEWORK}

Theory of the $\pi$-complexation of olefins with transition metal ions.

Transition metals, such as silver, are characterized for the presence of d-orbitals and a vacant s-orbital; therefore, the $\mathrm{Ag}^{+}$ion is able to bind specifically and reversibly with olefins, by means of donation and back-donation of electrons. Olefin molecules donate $\pi$-electrons from their occupied 2 p-orbitals to the vacant 5 s-orbital of the silver ion to form $\sigma$-bonds (Mingos, 2001).

Furthermore, back-donation of electrons from the occupied 4d-orbitals of the silver ion into the empty $\pi^{*}$ $2 p$ anti-bonding orbitals of the olefin molecule results in $\pi$-bonds (Hamouda, Nguyen, Langevin \& Roudesli, 2008). The concept of the $\pi$-complexation is depicted in Figure 1.

According to the above, the theory of $\pi$-complexation explains the chemical affinity of the silver ion to light olefinic compounds such as ethylene, propylene and butylenes, and its selectivity to separate them from paraffinic compounds.

Moreover, other potential applications of chemical complexation with $\mathrm{Ag}^{+}$such as separation of aromatic 
from aliphatic compounds (Bryant, Noble \& Koval, 1997; Chakraborty \& Bart, 2007; Kao, Wang \& Lue, 2002; Teramoto, Matsuyama \& Yonehara, 1990) and $\alpha$-olefins from internal olefins, have been reported (Song, Yu \& Cheng, 2008; Bessarabow et al., 1999).

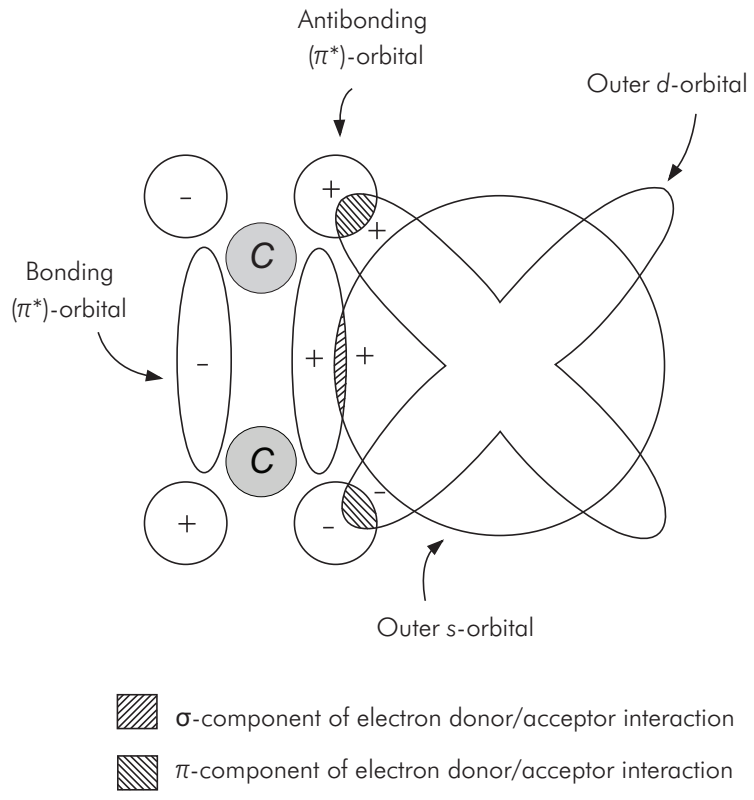

Figure 1. Metal-olefins complex (Song et al., 2008)

The selectivity of a silver salt $(\operatorname{AgX})$ depends on its lattice energy (Ortiz et al., 2008), which is an estimation of the strength of the bonds between the ions in the salt. In the case of most commonly studied silver salts, $\mathrm{AgBF}_{4}$ has the lowest lattice energy and exhibits higher selectivity than $\mathrm{AgNO}_{3}$ (Azhin, Kaghazchi \& Rahmani, 2008; Ortiz et al., 2008).

\section{Separation techniques based on the $\pi$-complexation concept}

Based on the mechanism of $\mathrm{Ag}^{+} \pi$-complexation, the possible techniques where this principle could be used are: absorption, liquid-liquid extraction, liquid membranes and solid membranes.

Considering that absorption and liquid-liquid extraction are often used in process industry, only liquid and solid membranes will be briefly explained. In the case of ethylene and propylene separation, the following concepts have been reported:

\section{Facilitated Transport Membrane (FTM)}

This is a solid membrane impregnated with the carrier, which in this specific case are $\mathrm{Ag}^{+}$ions. The carrier agent acts as a shuttle to selectively transport one of the components from the feed to the product side of the membrane (Won et al., 2005; Ferraz et al., 2007; Hyum, Wook, Sik, Keun \& Soo, 2009).

\section{Liquid Membranes (LM)}

A LM can be defined as a thin liquid film separating two liquid or gaseous phases and controlling the mass transfer between these phases.

The main advantage of this kind of membrane, compared to the solid membranes, is the higher solubility and diffusivity coefficients in a liquid medium versus a solid one.

There are three basic types of liquid membranes:

- Bulk fluid liquid membranes (BFLM) (Chakraborty \& Bart, 2007; Teramoto et al., 1990).

- Emulsion liquid membranes (ELM).

- Supported liquid membranes (SLM): Thin sheet SLM and Hollow Fibers SLM (Ravanchi, Kaghazchi \& Kargari, 2008).

\section{METHODS AND PROCEDURE}

\section{Definition of the benchmarks (current technology)}

The benchmarks to compare the performance of the chemical affinity techniques in ethylene and propylene separation were the technologies commonly used in the industry: cryogenic distillation for ethylene separation and conventional distillation for propylene separation (see Table 1). 
Table 1. Conventional technologies used for ethylene and propylene separation

\begin{tabular}{|c|c|c|}
\hline Type of separation & Ethylene from ethane & Propylene from propane \\
\hline Current technology & Cryogenic distillation & Convention al distillation \\
\hline Typical feedstock & $\begin{array}{l}\text { Ethane/ethylene mixture from steam cracking } \\
\text { furnace }\end{array}$ & Propane/propylene mixture from FCC - VRU \\
\hline Design production capacity & $100 \mathrm{kt} / \mathrm{y}$ of ethylene & $200 \mathrm{kt} / \mathrm{y}$ of propylene \\
\hline $\begin{array}{l}\text { Typical composition of } \\
\text { feedstock to splitter column }\end{array}$ & Ethylene: 56 vol\% / Ethane: 44 vol\% & $\begin{array}{c}\text { Propylene: } 75 \text { vol\% / Propane: } 24 \text { vol\% } \\
\text { Others (Ethane, Isobutane): } 1 \text { vol\% }\end{array}$ \\
\hline
\end{tabular}

To obtain the data related with the energy requirements and process yields, a simulation in ASPENTM Plus was done for both applications by using Peng-Robinson Equation of State. In the case of the affinity techniques, data from literature was used.

The investment cost estimation of the equipment was done according to the methodology by Zevnik \& Buchanan (1963), which is based in several factors related to the process severity and plant capacity. The results from ASPENTM Plus simulation and the economic evaluation are used as criteria to evaluate the different alternatives.

\section{Performance of $\pi$-complexation based techniques and comparison with benchmarks}

Several separation techniques based on $\pi$-complexation of $\mathrm{Ag}^{+}$were selected from literature. To compare the expected performance of the $\mathrm{Ag}^{+} \pi$-complexation technologies with their respective benchmark, some calculations were performed to obtain the key data at the same comparison basis.

Finally, in order to determine the feasibility of the $\mathrm{Ag}^{+} \pi$-complexation techniques, they were compared with the defined benchmarks. The feasibility was evaluated in terms of the order of magnitude of mass transfer fluxes, type of equipment to be used, equipment size, and investment and operational costs (CAPEX \& OPEX analysis). It must be noted that OPEX is strongly related with the silver salt make up needed for the process.
The main assumptions considered for carrying out the economic evaluation are listed in Table 2:

Table 2. Main assumptions for economic evaluation

\begin{tabular}{|c|c|}
\hline Assumption & Activity \\
\hline Price of silver nitrate & $\begin{array}{c}889 \text { US } \$ / k g \text { (Salt Lake Metals, } \\
\text { Inc., 2009) }\end{array}$ \\
\hline Construction cost index & $\begin{array}{l}609 \text { (Marshall, O'Rourke, } \\
\text { Lozowski \& Ondrey, 2008) }\end{array}$ \\
\hline Electricity cost & 0,088 US\$/kWh \\
\hline Cooling water cost & $0,01 \cup S \$ / m^{3}$ \\
\hline Steam heating cost & $\begin{array}{c}18 \text { US } \$ / \text { ton } \\
\text { (Cleaver Brooks, Inc., 2009) } \\
\text { (UE System Inc., 2009) }\end{array}$ \\
\hline Labor cost & 1,0 MM-US\$/year \\
\hline Pay-out time & 5 years \\
\hline
\end{tabular}

\section{RESULTS}

\section{Performance of the benchmarks}

Based on data obtained from the ASPENTM Plus simulations, the performance of the benchmarks for ethylene and propylene separation is presented in Table 3: 
Table 3. Performance of benchmarks for ethylene and propylene separation

\begin{tabular}{|c|c|c|c|}
\hline Parameter & Units & Ethylene Separation & Propylene Separation \\
\hline Production rate & ton/year & 100000 & 200000 \\
\hline Purity & vol\% & 99,95 & 99,95 \\
\hline Impurities & Ppm & $\begin{array}{l}C_{1}, 67 \\
C_{2}, 423\end{array}$ & $\begin{array}{l}C_{2}, 344 \\
C_{3}, 70\end{array}$ \\
\hline Recovery & vol\% & 99,9 & 99,9 \\
\hline Feedstock rate & ton/year & 180000 & 266000 \\
\hline \multicolumn{4}{|c|}{ Feedstock composition } \\
\hline \multicolumn{2}{|c|}{ Methane } & 37 ppm-vol & - \\
\hline \multicolumn{2}{|l|}{ Ethylene } & 55,5 vol\% & - \\
\hline \multicolumn{2}{|l|}{ Ethane } & 44,3 vol $\%$ & 190 ppm-vol \\
\hline \multicolumn{2}{|l|}{ Propylene } & 0,3 vol\% & 75,3 vol\% \\
\hline \multicolumn{2}{|l|}{ Propane } & - & 24,2 vol\% \\
\hline \multicolumn{2}{|l|}{ Isobutane } & - & 0,5 vol $\%$ \\
\hline No. Trays & - & 72 & $211^{(2)}$ \\
\hline Top pressure & Bar & 19,2 & 17,6 \\
\hline Reflux ratio & $\mathrm{Mol} / \mathrm{mol}$ & 6,0 & 25,2 \\
\hline Condenser duty & $M M-k J / h$ & $-24,56$ & $-171,22$ \\
\hline Reboiler duty & $M M-k J / h$ & 21,21 & 177,55 \\
\hline CAPEX ${ }^{(1)}$ & MM-US\$ & 21,88 & 25,46 \\
\hline Prod. cost ${ }^{(3) / 4)}$ & US\$/ton & 621,72 & 1056,49 \\
\hline \multicolumn{4}{|l|}{ Remarks: } \\
\hline \multicolumn{4}{|c|}{ 1. Grassroots unit } \\
\hline \multicolumn{4}{|c|}{ 2. 2 columns, 1 as stripper and 1 as rectifier } \\
\hline \multicolumn{4}{|c|}{$\begin{array}{l}\text { 3. Production cost calculated by accounting utilities consumption given by ASPEN } \\
\text { TM } \\
\text { applying Zevnik-Buchanan method to estimate CAPEX (Zevnik \& Buchanan, 1963) }\end{array}$} \\
\hline \multicolumn{4}{|c|}{ 4. Price of ethylene and propylene in the international market between 950-1200 and 1100-1300 } \\
\hline
\end{tabular}

Mass transfer data for proposed $\pi$-complexation techniques

The expected performance and tested process conditions for each application are shown in Tables 4 and 5.
The used criteria to make the preliminary evaluation and selection of promising affinity techniques in each application were purity and recovery of the main product; in the case of membranes, perrmeance was also included, because it defines the required area for separation. 
Table 4. $\pi$-complexation techniques for ethylene separation

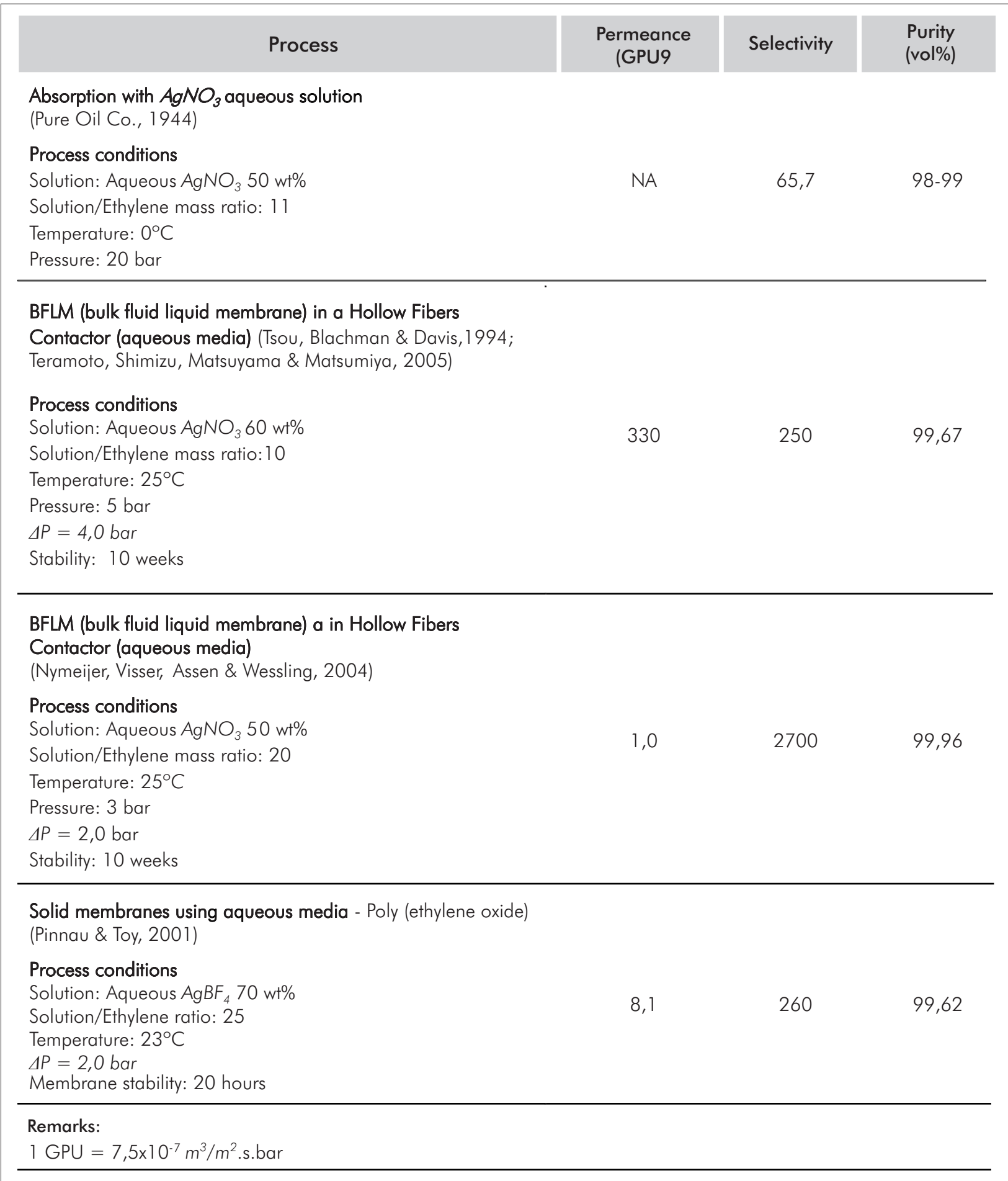

From Table 4, it can be seen that the Bulk Fluid Liquid Membranes (BFLM) in Hollow Fibers is the most promising technique to be applied in ethylene separation from ethane (Tsou, Blachman \& Davis, 1994; Teramoto et al., 2005), since such a type of membranes present the highest purity of the ethylene product. 
Table 5. $\pi$-complexation techniques for propylene separation

\begin{tabular}{|c|c|c|c|}
\hline Pressure & $\begin{array}{l}\text { Permeance } \\
\text { (GPU) }\end{array}$ & Selectivity & $\begin{array}{l}\text { Purity } \\
\text { (vol5) }\end{array}$ \\
\hline $\begin{array}{l}\text { Absorption with aqueous solution } \\
\text { (Ortiz et al., 2008) } \\
\text { Process conditions } \\
\text { Solution: Aqueous } \mathrm{AgBF}_{4} 15 \mathrm{wt} \% \\
\text { Solution/Propylene mass ratio: } 27 \\
\text { Temperature: } 25^{\circ} \mathrm{C} \\
\text { Pressure: } 2 \text { bar }\end{array}$ & NA & 39,2 & 97,5 \\
\hline $\begin{array}{l}\text { Absorption with RTIL solution } \\
\text { (Ortiz et al., 2008) } \\
\text { Process conditions } \\
\left.\text { Solution: } \text { AgBF }_{4} 15 \text { wt\% in RTIL (bmim-BP }{ }_{4}\right) \\
\text { Solution/Propylene mass ratio: } 27 \\
\text { Temperature: } 25^{\circ} \mathrm{C} \\
\text { Pressure: } 2 \text { bar }\end{array}$ & NA & 9,4 & 90,3 \\
\hline $\begin{array}{l}\text { SLM in tri-ethylene glycol media support: } \\
\text { Polytetrafluoroethylene } \\
\text { (PTFE) microporous membrane (2 layers) } \\
\text { (Duan, Ito \& Ohkawa, 2002; Ravanchi, Kaghazchi \& Kargari, 2009) } \\
\text { Process conditions } \\
\text { Solution: Aqueous } \mathrm{AgBF}_{4} 50 \text { wt\% } \\
\text { Solution/Propylene mass ratio: } 9 \\
\text { Temperature: } 25^{\circ} \mathrm{C} \\
\text { Pressure: } 1 \text { bar } \\
\Delta P=1,0 \text { bar } \\
\text { Membrane stability: max. } 3 \text { weeks }\end{array}$ & 8,1 & 54,7 & 98,2 \\
\hline $\begin{array}{l}\text { Solid membrane } \\
\text { Poly-2-ethyl-2-oxazoline (POZ) (Kim et al., 2007; Kang et al., 2008) - } \mathrm{Ag}^{+} \\
\text {supported on the membrane, using a solution of } \mathrm{AgNO}_{3} 70 \mathrm{wt} \% \text { in RTIL } \\
\left(\text { bmim- } \mathrm{NO}_{3} \text { ) }\right.\end{array}$ & 4,3 & 88,0 & 98,9 \\
\hline $\begin{array}{l}\text { Process conditions } \\
\text { Temperature: } 23^{\circ} \mathrm{C} \\
\text { Pressure: } 3 \text { bar } \\
\Delta P=2,0 \text { bar } \\
\text { Membrane stability: No stability data available }\end{array}$ & & & \\
\hline $\begin{array}{l}\text { Remarks: } \\
1 \mathrm{GPU}=7,5 \times 10^{-7} \mathrm{~m}^{3} / \mathrm{m}^{2} . \mathrm{s} . \text { bar }\end{array}$ & & & \\
\hline
\end{tabular}

From Table 5, the most promising membrane technique to be applied in propylene separation is the SLM (Supported Liquid Membrane) in PTFE (Ravanchi et al., 2008), due to its higher permeance.
Even though the solid membrane shows a higher selectivity to propylene (Kim et al., 2007; Kang et al., 2008), in both cases a further separation step would be required to achieve the petrochemical grade. 
On the other hand, absorption with aqueous solution cannot be discarded yet, because the feasibility of the SML will depend on the required membrane area.

The above results and further design calculation are used to compare affinity techniques with the benchmark in the discussion section. In addition, a feasibility analysis is done, in order to conclude whether these techniques are suitable or not for the proposed applications.

\section{CALCULATIONS AND DISCUSSION}

In this section, based on the results previously shown, the main design variables to achieve the purity requirements for each application are calculated, as well as the associated production cost. The results of the calculations and the discussion are presented first for ethylene/ethane separation, and subsequently for propylene/propane separation.

\section{Ethylene/ethane separation analysis}

Table 6 shows the requirements of membrane area and flow of carrier solution for a production of 100000 ton/year of ethylene, by applying bulk fluid liquid membranes (Nymeijer et al., 2004; Teramoto et al., 2005).

The second membrane BFLM 2 (Nymeijer et al., 2004) achieves the required petrochemical purity, but the required area is too large, making this kind of membrane technically non feasible. On the other hand, with the first membrane BFLM 1 (Teramoto et al., 2005) it is not possible to achieve the required purity; however, the calculated area is technically feasible and the required flow of carrier solution is much lower.

Considering the above, a hybrid process combining membrane and distillation technology is proposed as an alternative to the current cryogenic distillation process, using the first BFLM (Teramoto et al., 2005). It must be mentioned, that the hybrid process does not eliminate the required cryogenic process conditions in the distillation column, but it does reduce the operational costs.

Table 6. Required area and silver salt solution flow for standalone membrane modules

\begin{tabular}{|c|c|c|c|}
\hline Parameter & Units & BFLM 1 & BFLM 2 \\
\hline Ethylene production & $(\mathrm{kg} / \mathrm{s})$ & 3,17 & 3,17 \\
\hline Ethylene production & $\mathrm{m}^{3} / \mathrm{s}^{(1)}$ & 0,5533 & 0,5533 \\
\hline Selectivity $\mathrm{C}_{2} \mathrm{H}_{4} / \mathrm{C}_{2} \mathrm{H}_{6}$ & - & 250 & 2700 \\
\hline Product purity & vol\% & 99,67 & 99,96 \\
\hline Permeance & GPU & 330 & 1 \\
\hline Permeance & $\mathrm{m}^{3} / \mathrm{m}^{2}$.s.bar & $2,48 \times 10^{-4}$ & $7,50 \times 10^{-7}$ \\
\hline \multicolumn{4}{|l|}{ Process conditions } \\
\hline Conc. $\mathrm{AgNO}_{3}$ solution & $w+\%$ & 60 & 50 \\
\hline Solution/Ethylene ratio & $\mathrm{kg} / \mathrm{kg}$ & 10 & 20 \\
\hline Membrane $\Delta P$ & Bar & 4,0 & 2,0 \\
\hline Membrane area ${ }^{(2)}$ & $m^{2}$ & 560 & 370000 \\
\hline Flow of carrier sol:.3 & $\mathrm{kg} / \mathrm{s}$ & 31,8 & 63,4 \\
\hline \multicolumn{4}{|c|}{$\begin{array}{l}\text { Remarks: } \\
\text { 1. At } 25^{\circ} \mathrm{C} \text { and } 5 \text { bar } \\
\text { 2. Membrane area calculated as: } \\
\text { A }=\text { Flow/(Permeance } x \Delta P \text { ) } \\
\text { 3. Density of carrier solution is approximately } 1200 \mathrm{~kg} / \mathrm{m}^{3} \\
\text { 4. All data calculated for a feedstock of } 180 \mathrm{kton} / \text { year } \\
\text { (composition given in Table 3) and an ethylene production } \\
\text { of } 100 \mathrm{kton} / \text { year, considering } 8000 \text { hours of annual service }\end{array}$} \\
\hline
\end{tabular}

The proposed schematic diagram for the ethylene/ ethane separation at lab-scale by using a BFLM, with a silver nitrate solution as carrier is described by Teramoto et al. (2005).

In this system, an aqueous silver nitrate $\left(\mathrm{AgNO}_{3}\right)$ solution and a feed gas, consisting mainly of ethylene and ethane, are continuously supplied to the feed side (lumen side, high-pressure side) of a hollow fiber ultra-filtration membrane module, where the $\mathrm{AgNO}_{3}$ solution absorbs the ethylene selectively. The solution is forced through the membrane to the permeate side (shell side, low pressure side), where the solution releases the ethylene and the liquid is recycled to the lumen side by a pump (see Figure 2). 
Two configurations of the membrane-distillation hybrid system can be analyzed: membrane modules allocated in parallel or in series with the distillation column. These two systems have been studied previously by Al-Rabiah, (2003), demonstrating that series configuration is economically more attractive due to the greater energy saving.

Therefore, only the series configuration of the hybrid membrane/distillation process is considered. A scheme of such a configuration is depicted in Figure 3:

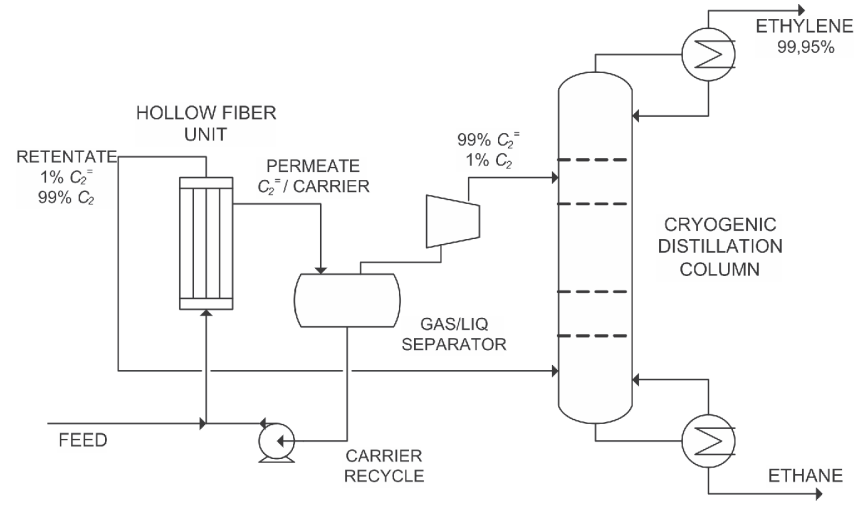

Figure 2. Series configuration for membrane/distillation process

The results of comparing the membrane/distillation hybrid process with conventional cryogenic distillation are summarized in Table 7.

In this table, the hybrid process is considered as both a grass-root unit and a revamped conventional process where a membrane module is added in series. In the last case, two alternatives of revamping are considered: energy saving or increasing of capacity. During the calculations the following assumptions were considered:

a. Concentration of silver solution: $60 \mathrm{wt} \% \mathrm{AgNO}_{3}$ (aqueous solution).

b. Time of stability of the solution: 10 weeks (every 10 week will be needed to replace a $5 \%$ of the solution) (Nymeijer et al., 2004).

c. Pressure drop across the membrane: 4 bar.

d. Price of hollow fiber membrane: 900 US $\$ / m^{2}$ (Futselaar, Zoontjes, Reith \& Rácz, 1993).

e. Membrane permeance: $2,48 \times 10^{-4} \mathrm{~m}^{3} / \mathrm{m}^{2}$.s.bar.

f. Membrane life time: 5 years.
After process and economic analysis, the hybrid grass-roots unit presents a similar investment cost and higher operational expenditure compared to the cryogenic distillation unit; however the energy consumption is about a half, supposing a lower $\mathrm{CO}_{2}$ print-foot.

Nevertheless, a deeper study on the $\mathrm{CO}_{2}$ print-foot contribution of the silver salt make-up should be done in a further work.

Considering the above, the production cost of ethylene petrochemical grade by means of a grassroots hybrid process is a bit higher than the cryogenic distillation process. On the other hand, applying the hybrid process as a revamping to reduce the energy consumption or increase the capacity of an existing unit would lead to savings in the total production cost, with a profitability of about 5,4 MUSD/year and 14,2 MUSD/year respectively.

\section{Propylene/propane separation analysis}

From Table 5 it can be seen that the higher values of purity are given by the membranes; however, no one of them can meet the petrochemical purity. Nevertheless, the Supported Liquid Membrane (SLM) was selected to make a preliminary evaluation, due to its higher permeance (Ravanchi et al., 2009).

This membrane consists in two layers of the support (microporous polytetrafluoroethylene, PTFE), in between of which a solution of $50 \mathrm{wt} \% A g B F_{4}$ in Tri-ethylene Glycol is used as permeant media.

A preliminary calculation was done in order to determine the required membrane. Since the permeance of the selected SLM is 8,1 GPU $\left(6,1 \times 10^{-6} \mathrm{~m}^{3} / \mathrm{m}^{2}\right.$.s.bar $)$ and the flow of permeate (propylene) $0,82 \mathrm{~m}^{3} / \mathrm{s}$ (at $25^{\circ} \mathrm{C}$ and 5 bar), the calculated membrane area would be approximately 135000 (at 1 bar of pressure drop), which is technically non feasible.

According to the above, absorption with silver salt solution was the next alternative to consider. As the selectivity of the absorption process is not enough to achieve the required purity of 99,95 vol\% (Ortiz et al., 2008), a hybrid process combining absorption with an aqueous silver nitrate $\left(\mathrm{AgNO}_{3}\right)$ and distillation was evaluated. 
Table 7. Process and economic analysis for ethylene/ethane hybrid separation process

\begin{tabular}{|c|c|c|c|c|c|}
\hline \multirow{2}{*}{ Parameter } & \multirow{2}{*}{ Units } & \multicolumn{2}{|c|}{ Grass-roots unit } & \multicolumn{2}{|c|}{ Revamped unit } \\
\hline & & $\begin{array}{l}\text { Cryogenic } \\
\text { distillation }\end{array}$ & $\begin{array}{l}\text { Hybrid } \\
\text { process }\end{array}$ & Energy saving & $\begin{array}{l}\text { Increasing of } \\
\text { capacity }\end{array}$ \\
\hline Ethylene Capacity & ton/year & 100000 & 100000 & 100000 & 209000 \\
\hline Number of trays distillation & - & 72 & 72 & 72 & 72 \\
\hline Top Pressure & bar & 19,6 & 19,6 & 19,6 & 19,6 \\
\hline Reflux ratio & $\mathrm{mol} / \mathrm{mol}$ & 6,0 & 2,6 & 2,6 & 2,6 \\
\hline Condenser Duty & $M M-k J / h$ & $-24,56$ & $-10,72$ & $-10,72$ & $-24,56$ \\
\hline Reboiler Duty & MM-kJ/h & 21,21 & 11,00 & 11,00 & 21,21 \\
\hline Membrane area & $\mathrm{m}^{2}$ & - & 560 & 560 & 1170 \\
\hline $\mathrm{AgNO}_{3}$ solution flow & $\mathrm{kg} / \mathrm{s}$ & - & 31,8 & 31,8 & 66,5 \\
\hline $\mathrm{AgNO}_{3}$ replacement & MM-US\$/year & - & 0,70 & 0,70 & 1,46 \\
\hline Raw material & MM-US\$/year & 41,29 & 41,29 & 41,29 & 86,29 \\
\hline Energy costs & MM-US\$/year & 1,95 & 0,99 & 0,99 & 2,05 \\
\hline Total OPEX ${ }^{(1)}$ & MM-US\$/year & 62,17 & 64,39 & 64,39 & 115,71 \\
\hline Membrane cost ${ }^{(2)}$ & MM-US\$ & - & 1,51 & 1,51 & 3,16 \\
\hline Silver salt inventory $\operatorname{cost}^{(3)}$ & MM-US\$ & - & 2,93 & 2,93 & 6,13 \\
\hline Other equipment cost ${ }^{(4)}$ & MM-US\$ & 21,88 & 17,02 & - & - \\
\hline Total CAPEX & MM-US\$ & 21,88 & 21,47 & 4,44 & 9,29 \\
\hline Production cost & US\$/ton & Base & $+22,18$ & $-54,41$ & $-68,11$ \\
\hline \multicolumn{6}{|c|}{$\begin{array}{l}\text { Remarks: } \\
\text { 1. Including the operational expenditure due to labor, raw material and energy } \\
\text { 2. Cost of installed membrane modules was considered as } 3 \text { times the cost of bare membrane modules, the later based on required membrane } \\
\text { area } \\
\text { 3. The amount of salt was calculated based on a residence time vessel of } 5 \text { min for a solution of } \mathrm{AgNO}_{3} 60 \mathrm{wt} \% \\
\text { 4. Capital expenditure due to conventional process equipment (distillation and refrigeration sections), calculated by means of Zevnik-Buchanan } \\
\text { method (Zevnik \& Buchanan, 1963), and scaled to } 2010 \text { by using the Chemical Engineering Plant Cost Index (Marshall etal., 2008) }\end{array}$} \\
\hline
\end{tabular}

It may be noted that the use of $\mathrm{AgBF}_{4}$ instead of $\mathrm{AgNO}_{3}$ is reported in the literature; however, in this work $\mathrm{AgNO}_{3}$ will be used as a first approximation to evaluate the economic feasibility, since $\mathrm{AgBF}_{4}$ is about eight times more expensive than $\mathrm{AgNO}_{3}$ (Azhin et al., 2008).

In this system, the propylene/propane feed in gas phase is contacted with an aqueous solution of $\mathrm{AgNO}_{3}$ $15 \mathrm{wt} \%$ in an absorber column, where the $\mathrm{AgNO}_{3}$ solu- tion absorbs the propylene selectively. Afterwards, the rich silver solution is stripped out in a vessel by applying pressure change and moderate heating, being the propylene released. Subsequently, the lean silver solution is recycled to the absorber by a pump.

After the absorption process, the $97-98$ vol\% propylene is fed to a conventional distillation column. The proponed schematic diagram is depicted in Figure 3: 


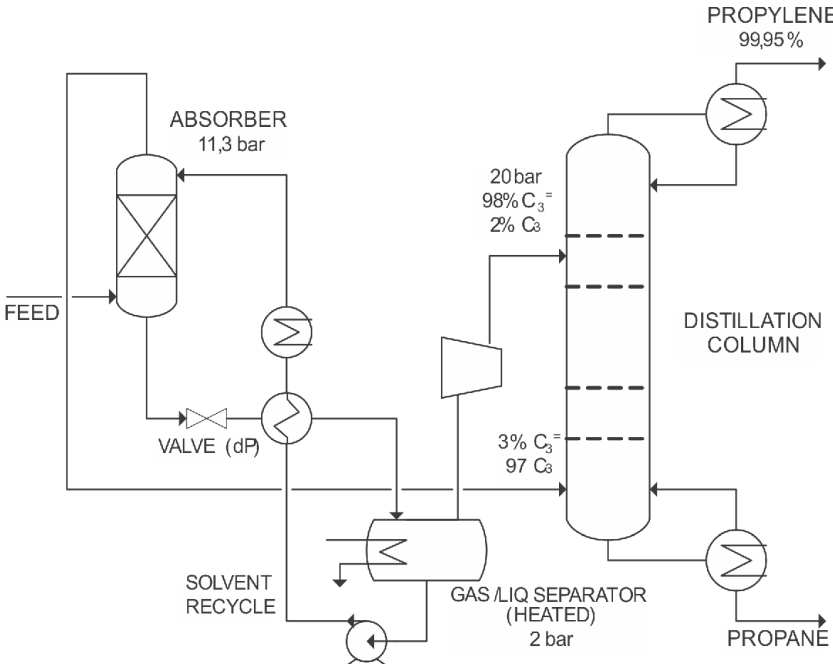

Figure 3. Absorption-Distillation hybrid system

For grass-roots unit, two alternatives can be considered for this hybrid system: reduction of number of stages to eliminate one of the sections of the distillation process at constant reflux ratio (reduction in CAPEX), and saving energy consumption by decreasing the reflux ratio at constant number of stages (reduction in OPEX). However, in this study only Alternative 2 was considered, based on the lower energy consumption and lower associated $\mathrm{CO}_{2}$ foot-print.

As in the case of ethylene/ethane separation, two revamping alternatives were evaluated as hybrid process options: energy saving and increasing of capacity of an existing distillation unit. The evaluation methodology was the same used in the ethylene separation case. The following assumptions were considered:

a. Concentration of silver solution: $15 \mathrm{wt} \% \mathrm{AgNO}_{3}$ (aqueous solution).

b. $\mathrm{AgNO}_{3}$ solution / propylene ratio: $27 \mathrm{~kg} / \mathrm{kg}$.

c. Time of stability of the solution: 10 weeks (replacing $5 \%$ of the solution) (Nymeijer et al., 2004).

d. Pressure in the absorber: 11,3 bar.

e. Pressure in the stripper vessel: 2,0 bar.
The results of the evaluation are summarized in Table 8. As in the previous ethylene/ethane separation analysis, the grass-roots unit presents a similar investment cost compared with the conventional distillation process. In this case, the required high flow of solvent contributes to a slightly higher energy cost, and at the end a higher production cost.

Again, when the $\mathrm{Ag}^{+}$complexation technology is applied to revamp an existing unit, in both alternatives energy saving and increasing of capacity, savings in the production cost are observed. In this case, a profitability of about 3,1 MUSD/year and 7,8 MUSD/year can be achieved respectively.

Nevertheless, in this case a clear reduction of energy consumption is not observed due to the energy requirement to re-pressurize the propylene after stripping it; therefore, the $\mathrm{CO}_{2}$ foot-print would be kept approximately constant. A further life cycle analysis study would be needed to determine the contribution of the process to the $\mathrm{CO}_{2}$ foot-print in a more accurate way.

\section{CONCLUSIONS}

According to the results and discussion presented in this study, the following conclusions can be made:

- $\mathrm{Ag}^{+} \pi$-complexation is technically feasible to separate commodity chemicals, as ethylene and propylene. In both cases, the hybrid processes were a better option over stand-alone $\mathrm{Ag}^{+} \pi$-complexation processes.

- The hybrid grass-roots unit is not an economic alternative to separate ethylene and propylene until petrochemical grade; nevertheless, in the case of ethylene separation, it can contribute to a lower $\mathrm{CO}_{2}$ foot-print.

- The process design showed that the utilization of hollow fiber membrane modules, with a $60 \mathrm{wt} \%$ $\mathrm{AgNO}_{3}$ solution as a carrier, can reduce in a $50 \%$ the energy consumption for ethylene separation or increase the plant capacity in a factor of 2, when applied for revamping existing units. $\mathrm{wt} \% \mathrm{AgNO}_{3}$ solution as a 
Table 8. Process and economic analysis for propylene/propane hybrid separation process

\begin{tabular}{|c|c|c|c|c|c|}
\hline \multirow{2}{*}{ Parameter } & \multirow{2}{*}{ Units } & \multicolumn{2}{|c|}{ Grass-roots unit } & \multicolumn{2}{|c|}{ Revanped unit } \\
\hline & & $\begin{array}{l}\text { Standalone } \\
\text { distillation }\end{array}$ & $\begin{array}{l}\text { Hybrid } \\
\text { process }\end{array}$ & Energy saving & $\begin{array}{l}\text { Increasing of } \\
\text { capacity }\end{array}$ \\
\hline Propylene capacity & ton/year & 200000 & 200000 & 200000 & 340000 \\
\hline Number of trays distillation & - & 211 & 211 & 211 & 211 \\
\hline Top pressures & bar & 17,6 & 17,6 & 17,6 & 17,6 \\
\hline Reflux ratio & $\mathrm{mol} / \mathrm{mol}$ & 25,3 & 14,6 & 14,6 & 25,3 \\
\hline Condenser duty & $M M-k J / h$ & $-171,22$ & $-98,60$ & $-98,60$ & $-171,22$ \\
\hline Reboiler duty & $M M-k J / h$ & 177,55 & 104,84 & 104,84 & 177,55 \\
\hline $\mathrm{AgNO}_{3}$ solution flow & $\mathrm{kg} / \mathrm{s}$ & - & 190 & 190 & 320 \\
\hline $\mathrm{AgNO}_{3}$ replacement & MM-US\$/year & - & 1,78 & 1,78 & 3,03 \\
\hline Raw material & MM-US\$/year & 154,78 & 154,78 & 154,78 & 263,12 \\
\hline Energy costs & MM-US\$/year & 16,74 & 17,82 & 17,82 & 30,23 \\
\hline Total OPEX ${ }^{(1)}$ & MM-US\$/year & 211,30 & 215,27 & 208,17 & 351,36 \\
\hline Absorber-Stripper unit ${ }^{(2)}$ & MM-US\$ & - & 4,33 & 4,33 & 5,96 \\
\hline Silver salt inventory cost ${ }^{(3)}$ & MM-US\$ & - & 6,86 & 6,86 & 11,66 \\
\hline Other equipment cost ${ }^{(2)}$ & MM-US\$ & 25,46 & 15,79 & - & - \\
\hline Total CAPEX & MM-US\$ & 25,46 & 26,98 & 11,19 & 17,62 \\
\hline Production cost & US\$/ton & Base & $+40,65$ & $-15,66$ & $-23,07$ \\
\hline \multicolumn{6}{|c|}{$\begin{array}{l}\text { Remarks: } \\
\text { 1. Including the operational expenditure due to labor and capital charge, in addition to raw material and energy }\end{array}$} \\
\hline \multicolumn{6}{|c|}{$\begin{array}{l}\text { 2. Capital expenditure due to process equipment, including absorption stripper-section, as well as conventional distillation, } \\
\text { calculated by means of Zevnik-Buchanan method (Zevnik \& Buchanan, 1963) and scaled to } 2010 \text { by using the Chemical } \\
\text { Engineering Plant Cost Index (Marshall et al., 2008) }\end{array}$} \\
\hline \multicolumn{6}{|c|}{ 3. The amount of salt was calculated based on a residence time vessel of $5 \mathrm{~min}$ for a solution of $\mathrm{AgNO}_{3} 15 \mathrm{w}+\%$} \\
\hline
\end{tabular}

carrier, can reduce in a $50 \%$ the energy consumption for ethylene separation or increase the plant capacity in a factor of 2 , when applied for revamping existing units.

- On the other hand, in the case of propylene separation, no net reduction in energy was achieved. There was, however, a $70 \%$ increase in plant capacity when absorption with a $15 \mathrm{wt} \% \mathrm{AgNO}_{3}$ solution is used to revamp an existing unit.

- At the studied capacities, the total production cost can be reduced about 50-70 US\$/ton for ethylene separation; whereas, for propylene separation, the reduction is around $15-25 \mathrm{US} \$ /$ ton.

\section{ACKNOWLEDGEMENTS}

The authors want to acknowledge Eng. Fabian Gómez from the Process Engineering Group of the Barrancabermeja Refinery, as well as Eng. Ernesto Sierra from the Economic Analysis Group of the same Refinery. Both of them contributed by supplying important process and economic data. 


\section{REFERENCES}

Al-Rabiah, A. (2003). The use of hybrid membrane distillation system for the Ethane Ethylene separation in olefin plants. 4th Ibero-American Congress on Membrane Science and Technology (CITEM). Rio de Janeiro, Brazil.

Azhin, M., Kaghazchi, T. \& Rahmani, M. (2008). A Review on olefin/paraffin separation using reversible chemical complexation technology. J. Ind. Eng. Chem. 14 (5), 622-638.

Bessarabow, D. G., Theron, J. P., Sanderson, R. D., Schwarz, H. H., Schossing, M. \& Paul, D. (1999). Separation of 1-hexene/n-hexane mixture using a hybrid membrane/ extraction system. Sep. and Purification Tech., 16 (2), 167-174.

Bryant, D., Noble R. \& Koval, C. (1997). Facilitated transport separation of benzene and cyclohexane with poly (vinyl alcohol)- $\mathrm{AgNO}_{3}$ membranes. J. Mem. Scie., 127: 161-170.

Chakraborty, M. \& Bart, H. J. (2007). Highly selective and efficient transport of toluene in bulk ionic liquid membranes containing $\mathrm{Ag}^{+}$as carrier. J. Fuel Proc. Tech., 88, 43-49.

Cleaver Brooks, Inc. (2009). Boilers steam cost calculator, Cleaver - Brooks, Inc. [Online calculator program]. [Consulted: April. 2009]. Available on $<$ http://www.cbbolilers. $\mathrm{com} / \mathrm{scc} /$ BoilerSteamCostCalculator.html $>$.

Duan, S., Ito, A. \& Ohkawa, A. (2002). Separation of propylene/propane mixture by a supported liquid membrane containing triethylene glycol and a silver salt. J. Mem. Scie., 215: 53-60.

Ferraz, H. C., Duarte, L. T., Di Luccio, M., Alves, T. L., Habert, A. C. \& Borges, C. P. (2007). Recent achievements in facilitated transport membranes for separation processes. Brazilian J. Chem. Eng., 24 (1), 101-118.

Futselaar, H., Zoontjes, R. J. C., Reith, T. \& Rácz, I. G. (1993). Economic comparison of transverse and longitudinal flow hollow fiber membrane mwodules for reverse osmosis and ultrafiltration. Desalination, 90: 345-361.

Hamouda, S., Nguyen, Q., Langevin, D. \& Roudesli, S. (2008). Facilitated transport of ethylene in poly (Amide 12-Block tetramethylenoxide) copolymer/AgBF4 membranes containing silver (I) and copper (I) ions as carriers. J. App. Scie., 8 (7), 1310-1314.
Hyum, S., Wook, S., Sik, J., Keun, S. \& Soo, Y. (2009). Enhanced olefin carrier activity of clean surface silver nanoparticles for facilitated transport membranes. J. Mem. Scie., 332: 1-5.

ICIS, Chemical industry news and intelligence (2008). Chemical and oil Price report, Reed Business Information Limited. [Report]. [Consulted: April 2009] Available on $<$ http://www.icis.com> - web site.

Kang, S. W., Hong, J., Char, K., Kim, J. H., Kim, J. \& Kang J. S. (2008). Correlation between anions of ionic liquids and reduction of silver ions in facilitated olefin transport membranes. Desalination, 233: 327-332.

Kao, S., Wang F. S. \& Lue S. L. (2002). Sorption, diffusion, and pervaporation of benzene/cyclohexane mixtures on silver-Nafion membranes. Desalination, 149: 35-40.

Kim, H. S., Park, S. J., Nguyen, D. Q., Bae, J. Y., Bae, H. G., Lee, H., Leeb, S. D. \& Choib, D. K. (2007). Multifunctional zwitterionic compounds as new membrane materials for separating olefin paraffin mixtures. Green Chem., 9: 599-604.

Li, M., Pham, P. J., Wang, T., Pittman Jr. C. \& Li, T. (2009). Selective extraction and enrichment of polyunsaturated fatty acid methyl esters from fish oil by novel $\pi$-complexing sorbents. Sep. and Purification Tech., 66: 1-8.

Li, M., Pittman Jr., C. E. \& Li, T. (2009). Extraction of polyunsaturated fatty acid methyl esters by imidazolium-based ionic liquids containing silver tetrafluoroborate - Extraction equilibrium studies. Talanta, 78: 1364-1370.

Marshall, R., O'Rourke, M., Lozowski, D. \& Ondrey, G. (2008). Plant Cost Index, Acess Intelligence. [Charts and tables] [Consulted: April 2009]. Available on $<$ http:// www.che.com/pci>.

Mingos, D. M. P. (2001). A historical perspective on Dewar's landmark contribution to organometallic chemistry. J. Org. Chem., 635: 1-8.

Newfoundland, J. (1998). Omega-3 fatty acid concentrates: nutritional aspects and production technologies. Trends Food Scie. Tech., 9 (6), 230-240.

Nymeijer, K., Visser, T., Assen, R. \& Wessling, M. (2004). Super selective membranes in gas liquid membrane contactor for olefin paraffin separation. J. Mem. Scie., 232: 107-114. 
Ortiz, A., Ruiza, A., Gorria, D. \& Ortiz, I. (2008). Room temperature ionic liquid with silver salts as efficient reaction media for propylene/propane separation: Absorption equilibrium. Sep. and Purification Tech., 63: 311-318.

Pinnau, I. \& Toy, L. G. (2001). Solid polymer electrolyte composite membranes for olefin paraffin separation. J. Mem. Scie., 184: 39-48.

Pure Oil Co. (1944) the. Concentration of low molecular weight aliphatic olefins from olefin-paraffin mixtures by absorption in $\mathrm{AgNO}_{3}$ solution, specially the concentration of butylenes from butylenes-butanes mixtures. Report for the Technical Oil Mission of the U.S. Bureau of Mines: Film Study Group Report on Microfilm, Reel (18). Chicago, USA.

Ravanchi, M. T., Kaghazchi, T. \& Kargari, A. (2008). Immobilized liquid membrane for propylene/propane separation. World Congress of Science, Engineering and Technology. Paris, France.

Ravanchi, M. T., Kaghazchi, T. \& Kargari, A. (2009). Application of membrane separation processes in petrochemical industry: a review. Desalination, 235: 199-244.

Salt Lake Metals Inc. (2009). Silver nitrate information, Salt Lake Metals, Inc. [Chemical specifications and prices]. [Consulted: April 2009]. Available on $<$ http://www.saltlakemetals.com/Silver_Nitrate.htm>

Song, F., Yu, Y. \& Cheng, J. (2008). Separation of C6 isomers in reactive extractants. Tsinghua Science and Tech.,13 (5), 730-735.

Teramoto, M., Matsuyama, H. \& Yonehara, T. (1990). Selective facilitated transport of benzene across supported and flowing liquid membranes containing silver nitrate as a carrier. J. Mem. Scie., 50: 269-284.

Teramoto, M., Shimizu, S., Matsuyama, H. \& Matsumiya, N. (2005). Ethylene/ethane separation and concentration by hollow fiber facilitated transport membrane module with permeation of silver nitrate solution. Sep. and Purification Tech., 44: 19-29.

Tsou, D., Blachman, M. W. \& Davis, J. C. (1994). Silver Facilitated olefin paraffin separation in a liquid membrane contactor system. Ind. Eng. Res., 33: 3209-3216.

UE System Inc. (2009). Steam production cost, UE Systems, Inc. [Charts and Graphics]. [Consulted: April 2009]. Available on <http://www.uesystemscom/ steam_cost.asp>
Won, J., Kim, D. B., Kang, Y. S., Choi, D. K., Kim, H. S., Kim, C. J. \& Kim, C. K. (2005). An ab initio study of ionic liquid silver complexes as carriers in facilitated olefin transport membranes. J. Mem. Scie., 260: 37-44.

Zevnik, F. \& Buchanan, R. (1963). General correlation of process investment. Chem. Eng. Progress, 59 (2), 70-77. 
